https://helda.helsinki.fi

\title{
Robert Kilwardby on Negative Judgement
}

\section{Silva, José Filipe}

2020-07

Silva , J F 2020 , ' Robert Kilwardby on Negative Judgement ' , Topoi , vol. 39 , no. 3 , pp.

667-677 . https://doi.org/10.1007/s11245-018-9577-x , https://doi.org/10.1007/s11245-018-9577-x

http://hdl.handle.net/10138/306939

https://doi.org/10.1007/s11245-018-9577-x

unspecified

acceptedVersion

Downloaded from Helda, University of Helsinki institutional repository.

This is an electronic reprint of the original article.

This reprint may differ from the original in pagination and typographic detail.

Please cite the original version. 


\title{
Robert Kilwardby on Negative Judgement
}

\author{
José Filipe Silva \\ Department of Philosophy, History, Culture and Arts Studies, University of Helsinki \\ jose.pereiradasilva@helsinki.fi
}

\begin{abstract}
In this article, I discuss Robert Kilwardby's (1215-1279) theory of judgement and consider its implications for his view of truth and falsity. I start by considering Kilwardby's claim that truth and falsity are primarily found in composite thought, i.e. judgement. I then examine his distinction between two different kinds of being, namely real and conceptual, arguing that different kinds of true judgement, according to Kilwardby, have different kinds of existential import, either real or merely conceptual. Since Kilwardby develops his position by commenting on Aristotle's logical treatises, an important aim of the article is that of showing how he addresses exegetical issues in those sources and offers solutions that go beyond Aristotle's alleged intentions. The focus of the paper is on negative judgement because that is where Kilwardby diverges from Aristotle most conspicuously.
\end{abstract}

Keywords: judgement, existential import, being, truth, medieval logic, Robert Kilwardby

\section{Introduction}

The Dominican Robert Kilwardby (1215-1279) is a well-known figure to scholars working on the history of philosophy and, in particular, on medieval logic. His commentaries on the so-called Old Logic, which mostly includes Aristotelian treatises, constitute an important part of the history of the development of medieval logical theories because they provide an early specimen of the reception of the Aristotelian logic in the recently instituted Faculty of Arts of the University of Paris.' His role in shaping medieval logic is made clear by the fact that his commentary on the Prior Analytics came to be used as the basic textbook for logic studies in the thirteenth century. Thus, any understanding of how Aristotelian medieval logic developed must start by understanding how Kilwardby understood

' On the Old Logic, see Cameron (2016: 195-219); on Kilwardby and the Old Logic, see Lewry (1978). For an introduction to Kilwardby's life and thought, see Silva (2016) and Silva (2012).

${ }^{2}$ See e.g. Uckelman and Lagerlund (2016: especially 120-23; 127-32). 
Aristotelian logic. It is important to keep this in mind for a proper assessment of Kilwardby's thought (in logic as well as in other issues): the degree of originality of other roughly contemporary authors, like Albert the Great or Thomas Aquinas, must be measured against the background of Kilwardby's logical theory. As the result of increased awareness of this fact, Kilwardby's logic has received renewed and well-deserved attention in recent years, with the publication of editions of his works and numerous scholarly articles. ${ }^{4}$ Many aspects of his logic, however, deserve further analysis. ${ }^{5}$

In what follows, I focus on Kilwardby's theory of judgement and consider its implications for his view of truth and falsity. ${ }^{6}$ s start by considering the claim that truth and falsity are primarily found in composite thought because thought primarily signifies things and linguistic expressions (written or spoken) signify things in the extra-mental world by signifying thoughts. I then examine the kind of being Kilwardby has in mind when discussing truth. The truth of judgements is dependent on things being as they are said to be. The issue is that there are different kinds of being, namely real (or extra-mental) and conceptual (or mental) being. Thus, the notion of truth and especially the existential import of judgements, affirmative and negative, must take this difference into account. One of the main aims of the article is to show the way Kilwardby plays the role of interpreter and commentator of Aristotle, explicitly addressing exegetical concerns, and trying to provide interpretations that respect Aristotle's original intentions. Although he largely succeeds in doing so, he also departs from Aristotle in important aspects that will be revealed throughout the paper.

\section{Affirmation and negation}

Robert Kilwardby, following Aristotle, discusses the relation between language, thought and existing things in three contexts. In his commentary on the De interpretatione, he analyses this relation from the perspective of how simple expressions and complex expressions signify thoughts, which in turn signify things in the extra-mental world. By simple expressions, he means single words and other non-sentential expressions (also discussed in the Categories), and by complex expressions he means statements, simple and complex. He further discusses this topic in his commentary to the Prior

\footnotetext{
${ }^{3}$ I cannot provide here a full-blown justification for this claim. For my purposes here, therefore, it suffices to point out that the existing scholarship agrees that Albert's logical commentaries depend on Kilwardby and that Aquinas' logical work depends on Albert (although they disagree on the extent of this influence). On the former, see Ebbesen (1981), Steel (2009), Conti (2013b). On the latter, see e.g. McMahon (2003).

${ }^{4}$ For an up-to-date bibliography, see Silva (2016).

s Thom (2007) briefly discusses some of these issues in different sections of the book, but with an exclusive focus on Kilwardby's commentary to the Prior Analytics.

${ }^{6}$ In what follows, I take statements as linguistic expressions of judgements. I will use both in order to keep closer to the terminology used in the passages I am interpreting.
} 
Analytics, where the approach is focused on the existential import of statements, both affirmative and negative. And finally, he discusses the topic in the De ortu scientiarum, where the focus is on the different kinds of knowledge. Let us proceed 'bottom-up', that is, from the definition of the basic notions in the De interpretatione.

According to the general picture in this work, the logician is interested in a sayable ordered with another sayable in a statement (dicibili ordinato cum dicibili in interpretatione enuntiatiua). There are two kinds of sayables in the statement, the name and the verb. Name and verb share three basic features: they are meaningful, simple and conventional.? They differ in that time applies to the verb but not to the name. The name is defined by Kilwardby, following Priscian, as substance together with quality. ${ }^{.}$That is to say, a name signifies a thing of a certain sort. Kilwardby remarks that there are two different approaches to conceptualizing the name, that of the grammarian and that of the logician. Whereas the grammarian starts by considering the name as a sound and proceeds to consider it as meaningful, the logician starts with the signification (or how it is understood by the intellect) and proceeds to the way it is expressed in a vocal sound. ${ }^{9}$ This division is also true of the way they consider complex expressions, for example the statement (oratio): whereas the logician considers the statement from the (semantical) point of view of the truth and falsity, thus with respect to the things signified that determine its truth-value, the grammarian considers it from the (syntactical) point of view of congruity (or well-formedness) or incongruity, which is caused by the connection and order among constituting elements (DI I.5, M 50ra). But Kilwardby is here also pointing out the fact that the existence of a name and a verb are not sufficient to constitute a statement, even if they could constitute a congruent grammatical expression (oratio perfecta gramatice loquendo).$^{10} \mathrm{~A}$ statement must be either true or false (DI I.2, M 46vb) and for that it must have a certain form, which is that of the declarative sentence (or assertion, enuntiatiua). The allusion here is to the original Aristotelian distinction between statement-making sentences and other sentences that do not say what is true or false (De interpretatione 17a2-7). Aristotle argues in the De interpretatione that utterances are taken to signify thoughts and only via thoughts do they signify things themselves." Kilwardby takes

\footnotetext{
Notule super librum Peryermenias (hereafter DI) (liber) I. (lectio) 2, M 45va: nomen et uerbum, que sunt principia materialia enuntiationis. I am grateful to Alessandro Conti for making available to me this forthcoming edition which is based on Lewry's transcription. The MSS for the edition are indicated with the following sigla: $\mathrm{M}=\mathrm{Madrid}$, Biblioteca Universitaria 73; P = Cambridge, Peterhouse 206; V = Venice, Biblioteca Marciana L.VI.66.

${ }^{*}$ DI I.3, M 47ra. See Priscian, Institutiones grammaticae, II.IV.18, 55.

DI I.1, P 66vb: differenter determinat dialecticus de nomine et gramaticus. Gramaticus enim secundum quod determinat de nomine considerat ipsum secundum quod incoat a uoce litterata et procedit ad intellectum; dialecticus uero considerat ipsum prout inchoat $a b$ intellectu et terminatur in uocem. On similar analyses of these different approaches in the Thirteenth Century, see Mora-Márquez (2015).

${ }^{10}$ DI I.2, M 46vb.

"Aristotle, De interpretatione 16a3-8. Boethius's interpretation of this passage, which influenced most of the late Middle Ages, has been studied in detail in Magee (1989).
} 
Aristotle to claim that the linguistic expression that falls within the scope of the De interpretatione, the statement, is constituted by terms that signify things themselves (dicentes ipsas res), i.e. things that belong to one of the ten kinds of being. ${ }^{2}$

One important distinction in these logical treatises is that arising between statement (enuntiatio) and proposition (propositio). ${ }^{13}$ In a very basic sense, both the statement and the proposition are defined as expressions that take something to be the case or not to be the case about something (NLPri I.2). But there are important differences between the two. The name and the verb are the material principles of the statement ${ }^{14}$ whereas proposition consists of the subject term and the predicate term (NLPri I.3, 72), the copula 'to be' considered as being part of the predicate (NLPri I.3, 74). Because of this difference, there can be a conversion only of propositions. The justification is that, whereas the proposition is constituted by two terms, one of which is predicated of the other, the statement is constituted by name and verb, the latter of which cannot simply be shifted to the subject place. A name does not acquire its role by the place it occupies in the statement, but rather by an act of signification (actu significandi: DI II.1, P 76rb). Because it 'exists only in meaningful terms' (NLPri I.1, 50), a statement can be considered on its own, i.e. from the point of view of the unity of its constituting terms, including the unity of signification. As such, it states primarily what is in the soul, and this way the true and the false (NLPri I.2,62). A proposition, on the other hand, is primarily considered from the point of view of its role in demonstrative reasoning, being subordinated to something else, namely to make something known in the conclusion. To make something known is the natural end of the syllogism of which the proposition is a part (NLPri I.1, 48-50); as such, a proposition (but not a statement) can be constituted by terms that do not refer to determined things but rather 'modes of things'.

'Modes of things' is an expression Kilwardby uses in other works, in particular in the De ortu scientiarum under the designation of modi or rationes rerum (DOS 454-ssg.), meaning things as conceptualized (or thought of) in a certain way. As such, these things as conceptualized can be related in thought to other things equally thus conceptualized. The expression appears in the context of the definition of a science of reasoning. Here, Kilwardby notes that the matter of reasoning is constituted by things, which belong to any one of the categories, and their modes or accounts (modi sive rationes rerum: DOS 448). What makes reasoning possible is that there are things to reason about, but also that these things exist and relate to other things in a certain way. To take Kilwardby's example, let us

\footnotetext{
${ }^{12}$ DI Proemium, P 66va: ex terminis significantibus res determinatorum generum.

${ }^{13}$ See e.g. Notule Libri Priorum (hereafter NLPri) I, lectio I, 98.

${ }^{14}$ See fn. 7 above.

is DI I.7, M 52ra: propositio est ex terminis huiusmodi qui non dicunt res determinatas, sed dicunt modos rerum.
} 
consider the case of geometry. Geometry uses terms such as line, continuum, divisible, etc. These things belong to the category of quantity, but it is because being divisible can be universally said of line that these terms can be part of a demonstration constituted by universal affirmative propositions, leading to scientific knowledge. But the universality that allows for such a demonstration is grounded on the universality implied in the things themselves. It is the existence of these modi rerum in things that makes them the subject of reasoning (including predication, one may add).$^{16}$ Of course, for the simple purpose of scientific reasoning, the terms constituting propositions can be completely abstracted from the things themselves, so that propositions can be constituted by transcendental terms only, that is to say, terms that do not signify things of any kind and thus can be represented by logical symbols (A, B, C). ${ }^{17}$ But this does not concern us here, as we will focus only on those propositions that are constituted by meaningful terms.

According to Kilwardby, a significant utterance (uox significatiua) can signify either naturally, like those produced by animals, or conventionally (ad placitum), like those produced by human beings, which are the result of an original act of imposition. (Here we are interested only in this latter kind.) Although the issue of signification is different from the question of truth, we can, in a broad sense, say that a simple utterance has a truth value: it is true if it signifies what actually exists (ens actuale), in the same way as for a thing to be true is for it to exist (DI I.2, M 46vb). But in a proper sense, only complex utterances have truth-values: a complex utterance like a statement, which is meaningful due to its constituting terms, signifies a state of affairs in which a predicate holds of a subject that, as such, is either true or false. In other words,

a thought sometimes is without truth and falsity, sometimes is with truth and falsity; and utterances are signs of thoughts; therefore, some utterances are without truth and falsity, and these are simple, and some are with truth and falsity, and these are complex.18

The passage starts by making the point that simple thoughts are without truth or falsity - or have it in a derived sense by signifying something-and that complex utterances do have a truth value by signifying indirectly, via thoughts, the way things are combined or related in the world external to

\footnotetext{
${ }^{16}$ De ortu scientiarum (hereafter DOS), paragraph 450: Isti igitur modi rerum sive rationes concrete cum rebus faciunt res rationalibles.

${ }^{17}$ DOS 451: termini [transcendentibus] qui nullius facultatis res significant. See also NLPri Prologue 36 and NLPri I.1, 50 .

${ }^{18}$ DI I.2, M 45vb: intellectus aliquando est sine uero et falso, aliquando cum uero et falso; et uoces sunt note intellectuum; ergo et uoces quedam sunt sine uero et falso, et sunt incomplexe, quedam cum uero et falso, et sunt complexe. 'Intellectus' here means the same as 'passio', which is the species (a likeness or representation of something) as understood or thought, i.e. as existing in the intellect (see DI I.2, M 46ra). He also notes that whereas thoughts are the same in all human beings, the words or signs are not. See Silva (2016) and Silva (2012).
} 
the thinking subject. In other words, a complex utterance is true if it combines (or divides) the subject term and the predicate term in a way that corresponds to the way the thing represented by the subject term and that which is signified by the predicate term are combined (or divided) in reality. Truth value is dependent in a primary sense on composition. Kilwardby notes, however, that there is in the Aristotelian text an ambiguity in the use of the expression 'composition' (compositio), as it can mean either the putting together of the two terms onto a proposition - in which case both affirmation and negation are compositions - or predicating something of something (DI I.2, P 68ra), which includes only affirmative propositions (as a negation consists in separating the predicate from the subject). ${ }^{19}$

So, complex thoughts, like the linguistic expressions that signify them, come in two modes: affirmative, which is the composition of the predicate with the subject, and negative, which is the separation of the predicate from the subject. Affirmation and negation are opposite statements because they indicate that the predicate is or is not said about the subject. Affirmative and negative statements cannot be simultaneously true; rather, one must be true and the other false, according to the principle of non-contradiction ${ }^{20}$ Kilwardby also considers the issue of the priority of affirmative and negative compositions with respect to the division into universal and particular (NLPri I.2, 623 ), and the priority of affirmation to negation. Although it would seem that negation comes first because non-being is prior to being, the fact is that everything that goes from potentiality to act does so by means of the action of something that is already in actuality. Thus, as to what is in actuality (thus being) is prior to what is in a state of potentiality, Kilwardby concludes that affirmation must be prior to negation, which is also Aristotle's own view. ${ }^{21}$ In fact, it should be said that up to now, Kilwardby has performed his duty as a commentator in an impeccable manner, as he closely follows the original Aristotelian texts. But more important than their priority is the question of how these express (or assume) a connection between meaning and truth, and if that is so in both the case of affirmative and negative statements.

Having introduced the basic distinctions operative in Kilwardby's logical theory, such as the distinction between a simple and complex expressions, I proceed to raise the central question I wish to address in this paper: what is the nature of negation and what kind of being this species of statement-making sentence entails. If a statement signifies something of something (aliquid de aliquo) it must be the case that every statement has an existential import; that is to say, is about being

\footnotetext{
${ }^{19}$ Contrast Aristotle's Metaphysics VI.4, 1027b24-5 and De interpretatione 6, 17a34-5. For an informative note on this issue, see Ackrill (1963, 125-27). This same point is noted by Crivelli (2004: 70); see also Whitaker (2008: 26 and especially 29).

${ }^{20}$ DI I.8, M 52va; see Aristotle, Categories 13b27-33.

${ }^{2}$ DI I.1, M 45va. See Aristotle, Metaphysics III.2, 996b14-16.
} 
(de ente). Therefore, there can be no statement which is about non-being (DI I.7, P 72va). Kilwardby is quick in his reply, noting that

it must be said that when I say that every statement is something of something, this 'something' is taken in a general sense, as something that could exist either in language only or in actual being (secundum rem); thus, when what is stated is about non-being according to actual existence, it is a statement about being at least in language, as in a statement about chimera or something like that.22

The claim is that when we predicate something of something, the subject of predication must exist, but it remains open as to what kind of being that this 'something' has. The question is whether existence in the realm of things is required for the truth of that judgement. Kilwardby's answer suggests that he is not willing to restrict the kind of existence required for the truth of a truth-making statement (or the judgement signified by it) to that of mind-independent material things. Instead, he takes this existence in a broad (communiter) sense. The name 'chimera' signifies something that has existence only in the mind (DI I.3, M 47vb). So, if one states that 'A chimera is white', the subject term has no being in reality, but it exists in thought and in the linguistic expression. In the background is the conception that there are different requirements in the cases of affirmative and negative statements. The basic claims are that affirmative statements are true of what exists (see Aristotle's Categories 14b11-18), whereas negations do not have that same existential import. What Kilwardby is suggesting is that this existential import should be taken as to also include mental or conceptual existence, so that what is said is true to the extent that it has a correspondence with what is thought, and thus that we can infer (mental) existence from predication. By doing so he seems to clearly diverge from Aristotle. ${ }^{23}$

\section{Existential import and not-being}

\footnotetext{
${ }_{22}$ DI I.7, M 52ra: Set dicendum quod cum dico omnem enuntiationem esse alicuius de aliquo, sumitur hoc ipsum "aliquid" communiter, siue fuerit aliquid secundum uocem tantum, siue secundum rem: unde cum de non ente secundum rem enuntiatur, est enuntiatio de ente ad minus secundum dictionem, ut cum enuntiatur de chimera uel de aliquo huiusmodi. On the medieval discussions concerning the existence of imaginary things like chimeras, see e.g. Biard (1985); Ebbesen (1986); and Dewender (2011). On how a similar idea is found later on in Martin of Dacia, see Mora-Márquez (2014: 37$8)$.

${ }^{23}$ De interpretatione 21a32-3: 'It is not true to say that what is not, since it is thought about, is something that is; for what is thought about it is not that it is, but that it is not' (trans. Ackrill). But how to take being in a predicative versus existential sense in Aristotle is a matter of dispute. See Jacobs (1979), Carson (2000), Charles (2000), and Kahn (1966).
} 
In this section, I will try to further explain what was suggested in the previous section, that is to say what Kilwardby takes to be the best rendering of Aristotle's claims on the existential import of predicative judgements by not restricting the notion of existence to something outside the mind. The focus will be first of all on necessary judgements and then on contingent judgements about the past and the future. In the following section, I will concentrate on negative judgements.

Kilwardby defines the contingent as that which can non-necessarily either be or not-be (NLPri I.18, 376), meaning that it can be described as the state of privation both with respect to the state of being necessary and with respect to the state of being impossible (non-being). But when it is conjoined with actuality, what is contingent has potentiality only for being only and not for non-being (NLPri I.18, 380-82). This view is aligned with Aristotle's statement according to which 'everything necessarily is while it is' ('omne quod est quando est necesse est esse') that we find in $D e$ interpretatione 9, 19a 23-27. This discussion in NLPri I.18 introduces the interesting question of whether the necessity of certain propositions, such as 'Men go grey' (example found in Aristotle's Prior Analytics 32b5), continues to exist even when there are no things (men, in this case) signified by the concepts signified by the proposition. Kilwardby starts answering this possible objection by recalling that Aristotle seems to suggest in some places that the truth of a proposition is dependent on the actual existence of things signified by the subject and predicate terms. ${ }^{24}$ In other words, the claim seems to be that for the proposition ' $\mathrm{X}$ is $\mathrm{Y}$ ' to be true, the things signified by $\mathrm{X}$ and by $\mathrm{Y}$ necessarily exist. This is supported by the thesis of convertibility of being and truth (verum et ens conuertuntur, NLPri I.18, 386). Thus, the truth of the proposition 'Man is an animal' is dependent on the truth of 'There are men'.

The problem with this is the claim, also found in Aristotle, that universals are imperishable, i.e. continue to exist even when the individuals instantiating them fail to do so. Kilwardby's solution for this rests on an understanding of being that includes, in addition to real or actual being, also habitudinal or conceptual being. Going back to the issue of what kind of being is necessitated by the truth of a proposition, the existence of some propositions such as 'The Antichrist will be a man' (NLPri I.18, 388) or 'A chimera is a chimera' would be simply false if being means actual being only. ${ }^{25}$ The question about truth and falsity seems to be dependent on a more basic question about what can be truly predicated and actually known. In order to answer this question, we must turn for a moment to another work by Kilwardby, the De ortu scientiarum.

\footnotetext{
${ }_{24}$ NLPri I.18, 386: Et ita ad ueritatem huius 'Homo est animal' requirirur ueritas huius 'Homo est'. Et ita ueritas propositionis exigit actualem entitatem subiecti et predicati. For Kilwardby, the statement has a unity of signification; see Conti (2013a: 75).

${ }_{25}$ See Roger Bacon, De signis, 141, 127.
} 
In chapter forty-seven of this well-known and much circulated classification of sciences, Kilwardby remarks that scientific knowledge concerns permanent things and that there can be no knowledge of non-being (de non ente). But there are many ways being can be said, and only about some of those ways can be said to be true. In a very Aristotelian manner, Kilwardby considers the way in which what we think can be expressed linguistically so that it respects the way things signified by the terms in the linguistic expression are in reality, via thought.$^{26}$ The truth value of what is linguistically expressed is parasitical on the way thought brings about the composition (or division) between conceptual items in the form of a judgement (NLP II.7, 382), and the truth of a mental composition (or division) is true with respect to the way things are in the extra-mental world (DOS 518). But there is another conception of truth: the truth of a thing is for a thing to be, so that for a thing to be ontologically false is for a thing not to be (NSLPery I.9, P 75va). This is a point that deserves emphasis: what Kilwardby is saying here is that there is a difference between epistemic truth and ontological truth, with the former being a property of thought and the latter being a property of things out there in the world. It is a difference between, on the one hand, things being or not being and, on the other, things being as we take them to be or not being so.

The focus of this paper, as indicated above, is on the epistemic sense of truth and falsity, i.e. existing in the intellect as in a subject, composing and dividing something of something else. This leads us to the core question of the kind of being a true statement requires, which arises from what Kilwardby perceives as being exegetical difficulties in the original Aristotelian texts. Kilwardby explicitly notes that there seems to be a conflict between two passages in Aristotle's works. In Metaphysics VI.4, ${ }^{27}$ Aristotle seems to suggest that truth or falsity is not said of what exists in reality but only of what exists in the mind, in combining and dividing the species of things. Kilwardby interprets this as meaning that, as these species and their combinations are beings of reason (res rationis, NLPri I.18, 390), no extra-mental realities are required for the truth or falsity of affirmative propositions: their truth is independent of the actual existence of things (ueritas propositionis esse possit sine actuali entitate rerum). But elsewhere, especially in Categories 14b18-22, Aristotle defines truth as the adequacy of composite thoughts and things, so that the combination of simple thoughts is true if and only if those things to which those composite thoughts are about are in the way

\footnotetext{
${ }^{26}$ Kilwardby is following one of the opening sentences of Aristotle's De interpretatione: 'spoken sounds are symbols of affections in the soul, and written marks symbols of spoken sounds' (16a3-5; trans. Ackrill).

${ }_{27}$ ' $[. .$.$] since that which is in the sense of being true, or is not in the sense of being false, depends on combination and$ separation [...] for falsity and truth are not in things - it is not as if the good were true, and the bad were in itself falsebut in thought' (Metaphysics VI.4, 1027b18-19, 25-27; trans. Ross).
} 
the thoughts have them being (NLPri I.18, 390). Therefore, the existence of extra-mental things is required for truth.$^{28}$ Elsewhere, this latter Aristotelian view is again presented:

statements (orationes) being true depend on things, that is they are determined as true or false according to the way things are determined to existence and non-existence. ${ }^{29}$

Kilwardby spots a lack of clarity, also noted by modern scholars, in Aristotle, who seems to leave unsaid in the Metaphysics passage what he makes explicit in the Categories, i.e. the thesis of a correspondence theory of truth: the cause of a true statement is found in the existence of extra-mental things signified by its terms. Of course, the passage occurs in a specific context, in which Aristotle is investigating what being means, but Kilwardby has a point in inquiring into whether there is a fault to be found in the thought of Aristotle. He tries to make sense of these passages with the help of Avicenna, who claimed that truth is an equivocal notion: in one sense, which applies to simple expressions, it is the being of the thing (entitas rei); in another sense, which applies to complex expressions, it is the adequacy of thing and thought (adequatio rei et intellectus).$^{30}$ In this way, one can say that truth is

in the thing as in its subject, in the speech as in its sign, and also in the thing as the effect in its cause and in the intellect as in the power of composition and division, i.e. as what is known is in the knower. ${ }^{31}$

In the continuation of the text, he makes it clear that to say that truth and falsity are in the statement as to be and not to be are in things is to say that what is signified by the subject term has whatever is being predicated of it - and not that the thing 'subject term' has it. The conception of truth at play

\footnotetext{
${ }^{28}$ I have hinted at this exegetical worry in Silva 2017. For discussion concerning this point in Aristotle, see Crivelli (2004, chapter 3). In the passage cited, Aristotle argues, in the context of a discussion over priority, that "whereas the true statement is in no way the cause of the actual thing's existence, the actual thing does seem in some way the cause of the statement's being true; it is because the actual thing exists or does not that the statement is called true or false' (Categories 12, 14b18-22; trans. Ackrill). See also Metaphysics VI.4, 1027b18-25.

${ }^{2}$ DI I.9, P 75va: Et hoc est quod dicit Aristotiles, orationes esse ueras quemadmodum et res, idest orationes sic se habere ad determinationem ueritatis uel falsitatis quemadmodum res ad determinationem existentie et non existentie.

${ }^{30}$ DI I.9, V 12v: Intellige quod ueritas dicitur equiuoce: est enim in incomplexis entitas rei, et hoc est quod dicit Auicenna, indiuisio esse, idest indiuisa rei entitas; et est ueritas in complexis, et sic dicitur adequatio rei et intellectus, et hoc est in enuntiationibus et in negatiuis de presenti et etiam in hiis de preterito. Ex ex hiis patet quid est ueritas. This definition of truth is found in Avicenna, Liber de Philosophia Prima sive Scientia Divina, Tractatus Primus, Capitulum Octavum, 5564.

${ }^{3}$ DI I.9, V 12v: [habitudo ueritatis] est in re tanquam in subiecto, et in oratione tanquam in signo, et est etiam in re tanquam effectus in sua causa, et in intellectu tanquam in uirtute compositiua uel diuisiuam, tanquam scilicet apprehensum in apprehendente.
} 
here is about the truth of things of which the statement is a sign. So, to say that Socrates runs means that there is an individual named Socrates who realizes that activity. ${ }^{32}$

This seems to suggest that the truth of that statement is dependent on the time of the statementmaking sentence. The necessity of truth is always relative to the time in which it is true: Socrates sits and it is possible that he would stand; but, he cannot both sit (sedere) and stand (stare), so that the truth of one is the destruction of the truth (denial) of the statement signifying the opposite (DI I.9, P $75 \mathrm{va})$. About past-tense affirmative statements that are true, their being true is necessary because what has happened cannot fail to have happened; but in the case of negative statements there is no such necessity because what has not happened could have happened. ${ }^{33}$ Kilwardby thus seems to suggest that there is a higher determinacy with respect to affirmative statements about the past-if things were as the statement had them being, they could not have been otherwise-but that this fails to apply to negative statements about the past: what has not been the case could have been the case. As to statements concerning the future, no truth value can be determined; what is clear, however, is that either the affirmation or the negation needs to be true (and the other false), despite it being impossible (for human beings) to know which will be the case ${ }^{34}$ In other words, with respect to present and past statements, their truth value is already determined and their necessity results from having been or actually being the case; but no such thing is the case with future-tense statements because contingent things show no necessary inclination for being or non-being (DI I.9, P 75va).

One of the reasons Kilwardby states that truth is in the intellect rather than in the things qua causes of thoughts is that, in some cases, certain mental statements can be true independently of whether those things, of which the thoughts are about, happen to exist at the time of judging. That is the case with statements that express a real definition. Whenever one states (or entertains) a real definition, that definition is true irrespectively of whether at the time of entertaining such a thought (of the definition) the things to which the definition applies exist. So, 'human beings are rational animals' is true, even if at this time there were no human beings. What is being signified here is the essence that is known and that is expressed in a definition..$^{35}$ Now, according to Kilwardby, there are

\footnotetext{
${ }^{32}$ DI I.9, V12v: Set intellige quod ueritas et falsitas est in oratione eo quod res est uel non est; set non dico hoc rem subiecti termini set magis illud quod significatur per orationem, secundum quod dicimus Sortem currere significari per hanc enuntiationem, 'sortes currit'.

${ }^{33}$ DI I.9, V 12v: in omni materia affirmatiua uera de preterito, cuius ueritas non dependet ex futuro, est necessaria; negatiua autem nequaquam. Et causa est quia quod factum est non potest non fieri, et quod nondum factum est potuit fuisse. It is important to note that Kilwardby thinks that for Aristotle, in negative modal propositions, what is negated is the 'to be' (the esse) rather than the mode, which is particularly important for their conversion (see NLPri I.8, 124-25; I.9, 142-43). ${ }^{34}$ DI I.9, M 55va: Propter hoc ergo dicimus quod in hiis de futuro est ueritas uel falsitas, non tamen determinata. God does, of course, know their truth value. See Knuuttila (2015).

${ }^{35}$ On the issue of the relation between signification and the truth value of assertions with empty terms as subjects, see e.g. Mora-Márquez (2015, especially chapter 2, section 2).
} 
two kinds of definition for the quid est of a thing: one, what the thing is (quid est rei) and two, what the name of the thing is ${ }^{36}$ So, if a thing does not exist, one cannot know what it is; but we can nevertheless know what its name signifies (quid significet). For instance, in the case of the goat-stag (yrcoceruus), there is something that is meant and understood by the word, despite there being no such thing in the world outside the mind that corresponds to that name. ${ }^{37}$ It is interesting to notice that Kilwardby prefers to talk about the goat-stag as something that is composed from information received from the senses about things existing outside the mind-and as such is conceivable or intelligible - rather than emphasizing how such a being cannot (and does not) exist in the extra-mental world. Kilwardby thus seems to be suggesting a close connection between signification and the truth value of statements, while Aristotle, on whom he is commenting, keeps the two apart.

There are two main claims being made here. One is that knowing what something is is different from knowing that it is; for instance, knowing what it is to be a human being is different from knowing that a human being exists (aliud et aliud est quid est homo et hominem esse, NLP II.7, 375). The other claim is that things exist in two different ways, namely in nature or in the mind. Since what is in the mind exists in the second sense of being we are able to predicate something of it. The existence of what is thus-and-so is accidental to what is thus-and-so, because there is only one being of which existence is predicated necessarily: God. What is particularly important in this is that Kilwardby does not dismiss those things that do not currently exist from the scope of scientific knowledge (Corbini 2013: 194). In the context of demonstrations, it is assumed that the subject of a proposition needs to exist for something to be predicated of it and to know what it is (see Posterior Analytics 93a20). Kilwardby addresses this issue by assigning different kinds of being to what is nonexisting, so that what is in a potential state, or which does not exist as such, can have at least a nominal definition..$^{38}$ Kilwardby thus argues that not to exist in actuality in nature does not necessarily entail not being known; rather, what has potential or habitudinal being can have a definition of its essence (NLP II.7, 380; see also NLPri I.18, 392). From this it follows that we can have demonstrations from what does not exist in actuality in nature, for instance a rose in the winter, as we can of what does so exist, like a circle-defined as a geometrical figure the sides of which are equidistant to the centre.

\footnotetext{
${ }^{36}$ Notule Libri Posteriorum (hereafter NLP) book II, lectio 7, page 382: et quia sermo est signum intellectus, propterea talia, ut chimera, possunt per sermonem significari et poni etiam illud intellectum, sicut est in intellectu sermone per partes explicari, et illud sic explicans non est diffinitio significans quid est rei, sed diffinitio indicans quid significat nomen. Patet etiam quod non entium extra animam, entium tamen alico modo in anima composite, est nomen et diffinitio indicans quid est nomen.

${ }^{37}$ NLP II.7, 374: non sit in rerum natura al<i>quid tale. See Aristotle, De interpretatione 16a15-6; and Metaphysics VII.4, 1030a17-27.

${ }_{38}$ William of Ockham will argue later on for a similar view (Summa Logicae, I, c. 26, 88). See Dewender (2011: 441). On Duns Scotus on the same topic, see Cesalli (2007: 132-37). For later developments, see Ashworth (1977). Whitaker (2008, Appendix III) analyses in detail the relation between signification and definition.
} 
The only exception are impossible things such as a chimera (NLP II.7, 380) ${ }^{39}$ Syllogistic is therefore not restricted to terms that stand for things that have mind-independent existence. The conclusion is then that 'the actual existence of things outside the soul is not always required for a proposition to be true' ${ }^{40}$

Even if Kilwardby, in building his argument, attempts to provide a faithful interpretation of Aristotle, he does go beyond the Greek philosopher in this extension of the notion of truth of statements about non-existing things. Aristotle would agree that we can predicate anything of a nonexisting subject, like a goat-stag; but for Aristotle, only negative propositions with non-existent subjects are true (Categories 13b20-35). By contrast, Kilwardby emphasises the complex nature of truth and that to be understood or rationally conceivable is a way of being true. The suggestion seems to be that, beyond what may be the intention of the Aristotelian texts he is commenting on, for Kilwardby existential import must include conceptual existence, and that this type of existence suffices for a sense of being true. ${ }^{41}$

\section{Existential import and negation}

Having examined the way Kilwardby address the question of the existential import of true and false judgements, I proceed to consider how negation impacts the truth value of statements. Kilwardby does this by focusing on the relation between privative and infinite or indefinite terms. He starts by saying that indefinite names are cases of term negation, in that an indefinite name results from adding a negative particle ('not') to the name ('man'). Due to that, an indefinite name ('not-man') is not a name simpliciter but a name in a qualified sense. It is not a name simpliciter because a name, as noted before, signifies substance with (determined) quality in such a way that it signifies a definite thing (DI 3, M 47vb); instead, an indefinite name signifies no such one thing. An indefinite name is undetermined because the added negative particle 'breaks' that composition of substance with quality and thus deprives the name of that qualified signification. Although this applies to the class of names in general, Kilwardby notes that because names are either substantives or adjectives (NLPri 47, 996), we must distinguish between indefinite names in substantive and in adjectival forms. We must do so

\footnotetext{
${ }^{39}$ This conception of existential import extended to possible things may be of Avicennian influence. On Avicenna's view, see Chatti (2016).

${ }^{40}$ NLP II:7, 381. That would put Kilwardby at odds with Thomas Aquinas. On Aquinas' view, see Bäck (2003) and Bäck (2011). On the criticism of the received view that, for Aristotle, negative categorical propositions have existential import in syllogistic reasoning, see Wedin (1990); for a defence of the view, see Kneale and Kneale (1962).

${ }^{4}$ I am grateful to the two reviewers, who insisted that I make this point clearer.
} 
because this impacts the existential import of indefinite names. In the substantive case, substance and quality 'do not differ essentially' and so when both are negated, there is no determinate signification left to the name and thus the indefinite name does not stand for anything (NLPri 47, 1005). In the adjectival case, however, it does. First, we must differentiate between names that designate an accidental form, like 'white' and 'just', and those that designate an essential form. Second, we must differentiate between pure negation, like 'no-one' (nemo), in which case nothing is posited neither in reality nor in thought (NLPri 47, 1009), and qualified negation, like 'not-man'. In this latter case, notman means the privation of the significant quality associated with the substance (NLPri 47, 1000), but does not mean pure lack of existence. In fact, not-man brings to the understanding - as a form of excitation-the consideration of what it signifies, i.e. the privation of form, and thus it posits something in thought (secundum animam et apprehesionem). Third, in the case of those names that designate accidental forms, the substance of which the accident is negated, is posited: "non-white posits something that is not white' (NLPri 47, 1009).

The difference between a privative term and an indefinite one is that the former "posits a potentiality or aptitude towards a form', like being blind posits a lack that entails the existence of an aptitude for seeing. The latter, or indefinite term, is simply the absolute lack of that quality, like not being a man (i.e. being a not-man) (NLPri 47, 980). Another way of explaining this is to say that a privative term denotes something that has the natural capacity and inclination to have such a property but actually fails to have it, like a blind person qua an animal has the natural capacity for seeing but happens to be currently impaired. In the case of an indefinite term, however, it denotes that this thing fails to have in absolute terms that property, i.e. it is everything but that property ${ }_{92}^{42}$ It applies to a wide range of objects: it can be a giraffe or a stone, but not a human being. Applying this to the question of existential import, Kilwardby notes that whereas an indefinite subject term posits nothing in the extra-mental reality - in the sense of what both is and could be-a privative term posits something in reality, while at the same time signifying the lacking of something: blind (cecum) posits animal, as only animals can be blind and unjust (iniustum) posits human being, as only human beings can be unjust. ${ }^{43}$

In this context, Kilwardby notes that the adjoining of a universal quantifier to the predicate term has an impact on the understanding of the distribution of the predicate to the subject:

\footnotetext{
${ }^{42}$ For Aristotle on privative terms, see Categories 12a28-33; on indefinite terms, De interpretatione 16a30-1.

${ }^{43}$ DI 3, M 47vb. See Thom (2007: 15-6).
} 
It can therefore be granted that 'every' can be added to the predicate, but if the proposition is affirmative the expression will always be false. However, if a negation comes on top of this falsity it demolishes it, the negative proposition still remains true. And on this account, it is said that 'every' can very well be added to the predicate of a negative proposition but not to the predicate of an affirmative, because in an affirmative it produces a falsehood, in a negative it removes that falsehood. (There could be an alternative reply, but a more careful discussion of this belongs in the De interpretatione.) (NLPri I.33, 749)

An example could be the judgement 'Every man is every animal,' which is clearly false; however, when we judge, 'No man is every animal,' the proposition is true. In DI, we find the exact continuation of this point to which Kilwardby referred in the passage from NLPri just quoted:

If every man is an animal, then every not-animal is a not-man; but a stone is a not-animal; therefore, a stone is a not-man. Therefore, [it follows] from the first, [that] 'if every man is an animal, a stone exists'; and this cannot be forbidden except if it is said that that 'not-man' posits nothing. ${ }^{44}$

The idea is that 'not-animal' and 'not-man' are predicates that are, like in any other affirmative proposition, being said of the subject (stone) (NLPri I.9, 144-45) and thus have an existential import, except if these negated predicate terms signify nothing. To use other examples from Kilwardby, 'to be not-equal' posits something as it is an affirmation and thus follows the general principle of propositional existential import, whereas 'not to be equal' posits nothing (NLPri 47, 964). As mentioned above, a name signifies a substance together with quality and, as such, has a circumscribed signification (DI I.3, M 48ra); but when one adds a negative particle to it, the name loses this restriction and it becomes indefinite. ${ }^{45}$ An indefinite term is that which means a lack of certainty as to whether its determination should be universal or particular (NLPri I.2, 66-7). 'Not-man' denotes a lack of determination with respect to 'man', so whereas man stands for being (ens), not-man stands for non-being (non-ens) and posits nothing in reality (in rerum natura). That does not mean, however, that it has no existence whatsoever; rather, it exists in the soul because it is part of a (composite)

\footnotetext{
${ }^{44}$ DI M 48ra: Item, 'Omnis homo est animal; ergo omne non-animal est non homo; set lapis est non-animal; ergo lapis est non-homo; ergo lapis est.' Ergo a primo, 'Si omnis homo est animal, lapis est,' et non est prohibere istud nisi dicatur quod li 'non-homo' nichil ponit: ergo ut prius. Thom (2007: 88) quotes a similar passage from the commentary on the Prior Analytics (NLPri 47, 1004), which further demonstrates the close connection between the two commentaries.

${ }_{45}$ According to Aristotle, Kilwardby says, and with respect to the quantity of statements, a totality can be either finite or infinite; if finite, it is universal; if infinite, it is indefinite (DI I.8, M 53ra).
} 
thought. In other words, adding a negative particle to a name does not require the existence in nature of what is signified by the name, but it still signifies something. This something signified by the name has conceptual being because the privation of something is still something (NLPri 47, 986-87). The same idea appears in DI 3 (M 48ra), where Kilwardby refers to Aristotle's reasoning that 'I see darkness' means that I see nothing, just like thinking 'not-man' is to think nothing in the sense of signifying no one thing determinately (NLPri 47, 1007). But, it signifies nothing in a different sense than 'buba' signifies nothing: not-man brings about an understanding, the understanding of privation of form. It excites the intellect to consider what the name stands for and as such posits something 'conceptually or in the imagination or linguistically', which 'buba' clearly does not (NLPri 47, 1013).

We must now consider, before concluding, how what has just been said changes according to whether the indefinite term plays the role of the subject or of the predicate in a statement. When it is the subject term that is indefinite, as in the statement 'A non-man is an $\mathrm{x}$ ' this leaves open many possibilities as to what stands for the subject 'non-man'. For instance, it could be a stone or a cat (NLPri 47, 1008-11). Those possibilities can, but do not necessarily, include something in nature. Therefore, all that can be said with certainty is that a statement with an indefinite subject term entails at least the existence of something in the mind. In the case of universal negative necessity propositions, however, the predicate is universally denied of whatever is and can be signified by the subject. $^{46}$ An indefinite predicate is stronger in terms of its existential import because, when the predicate is negated, it is removed from any part of the subject and everything that is denoted by the subject term (si negetur predicatum, remouetur a qualibet parte subjecti). Kilwardby concludes, then, that 'the negation rejects more than the affirmation states' (NLPri I.21, 522-23), which also means that it is less informative because it is less determinate. This explains why Kilwardby explicitly denies, in the form of a Prohibited thesis in 1277, that the validity of the inference 'Socrates is not just, thus Socrates is not-just' does not require the existence of the thing signified by the subject term (Tabarroni 2003; Lewry 1981). The reason for this is that an affirmative statement, like 'Socrates is not-just', assumes the existence of the subject in reality but that does not follow from the preceding negative 'Socrates is not just': this does not state existence in reality.

\section{Conclusion}

In this article, I examine different aspects under which Kilwardby discusses the notion of judgement and statement, especially negative statements in a logical context. The focus is on the issue of the

\footnotetext{
${ }^{4}$ NLPri 47, 1014. See Thom (2007: 26).
} 
existential import of such statements and the notion of truth entailed by them. Special attention is paid to the question as to the kind of existence required for a statement, affirmative or negative, to be true. Addressing differing views in the Aristotelian texts, as well as the specific contexts of analysis, Kilwardby tries to provide a solution for certain exegetical problems, for instance about the notion of composition and especially the apparent conflicting statements concerning the nature of truth. It is concerning this last aspect that Kilwardby seems to depart in a significant way from the Aristotelian texts he is commenting on. For Kilwardby, there is a sense in which the truth of a statement depends on the existence outside the soul of the things represented by their concepts in the soul. That is the view he assigns to Aristotle in the Categories. But there is another sense in which truth is dependent only on things as being combined or divided in thought, so that there is truth whenever there is understanding and irrespective of whether or not this corresponds to the actual existence of any extramental things those thoughts stand for. And that is the Aristotelian view Kilwardby finds in the Metaphysics, which applies to statements about fictional entities such as the chimera or the goat-stag as well as to negative statements. In the end, Kilwardby extends the Aristotelian position on the conditions of the truth of predicative statements beyond real being to conceptual being and thus associating truth (in a broad sense) to signification.

\section{Acknowledgements}

The author would like to acknowledge funding from the European Research Council under the ERC Starting grant agreement n. 637747 for the project Rationality in Perception: Transformations of Mind and Cognition 1250-1550. Many thanks are due to the guest editors of this volume, Mika Perälä and Sonja Schierbaum, for their suggestions and patience, as well as to Simo Knuuttila for his comments. In the final stages, this article has also benefited from important suggestions by two anonymous referees of Topoi.

\section{References}

Ackrill JL (1963) Aristotle's Categories and De Interpretatione. Clarendon Press, Oxford Aristotle, Analytica priora et posteriora. Ed. Ross WD. Clarendon Press, Oxford, 1964

Aristotle, Categoriae et liber De interpretatione. Ed. Minio-Paluello L. Clarendon Press, Oxford, 1949 Aristotle, Metaphysics (2 vols). Ed. Ross WD. Clarendon Press, Oxford, 1924

Ashworth E J (1977) Chimeras and Imaginary Objects: A Study in the Post-Medieval Theory of Signification. Vivarium 15.1:57-77 
Avicenna Latinus, Liber de Philosophia Prima sive Scientia Divina I-IV. Ed. S. Van Riet. PeetersBrill, Louvain-Leiden, 1977

Biard J (1985) La signification d'objets imaginaires dans quelques textes anglais du XIV siècle (Guillaume Heytesbury, Henry Hopton). In: Lewry O (ed) The Rise of British Logic. Pontifical Institute of Mediaeval Studies, Toronto, pp 265-83

Bäck A (2003) Aquinas on Predication. In: Braakhuis HAG, Kneepkens CH (eds) Aristotle's Peri hermeneias in the Latin Middle Ages. Essays on the Commentary Tradition. Brepols, Turnhout, pp $321-38$

Bäck A (2011) Two Aristotelian Theories of Existential Import. Aporía: Revista Internacional de Investigaciones Filosóficas 2:4-24

Cameron M (2016) Old Logic. In: Dutilh-Novaes C, Read S (eds) The Cambridge Companion to Medieval Logic. Cambridge University Press, Cambridge, pp 195-219

Carson S (2000) Aristotle on Existential Import and Nonreferring Subjects. Synthese 124.3:343-60

Cesalli L (2007) Le réalisme propositionnel: sémantique et ontologie des propositions chez Jean Duns Scot, Gauthier Burley, Richard Brinkley et Jean Wyclif. Vrin, Paris

Charles D (2000) Aristotle on Meaning and Essence. Oxford University Press, Oxford

Chatti S (2016) Existential Import in Avicenna's Modal Logic. Arabic Sciences and Philosophy 26.1:45-71

Conti A (2013a) Semantics and Ontology in Robert Kilwardby's Commentaries on the Logica vetus. In: Lagerlund H, Thom P (eds) A Companion to the Philosophy of Robert Kilwardby. Brill, Leiden, pp 65-130

Conti A (2013b) Robert Kilwardby and Albert the Great on Praedicamenta and Praedicabilia. In: Fink JL, Hansen H, Mora-Márquez AM (eds) Logic and Language in the Middle Ages: A Volume in Honour of Sten Ebbesen. Brill, Leiden, pp 155-69

Corbini A (2013) Robert Kilwardby and the Aristotelian Theory of Science. In: Thom P, Lagerlund H (eds) A Companion to the Philosophy of Robert Kilwardby. Brill, Leiden, pp 163-207

Crivelli P (2004) Aristotle on Truth. Cambridge University Press, Cambridge

Dewender T (2011) William of Ockham and Walter Burley on Signification and Imaginary Objects. In: Emery Jr. K, Friedman RL, Speer A (eds) Philosophy and Theology in the Long Middle Ages. A Tribute to Stephen F. Brown. Brill, Leiden, pp 437-50

Ebbesen S (1981) Albert (the Great?)'s companion to the Organon. In: Zimmermann A, Vuillemindiem G (eds) Albert der Grosse. Sein Zeit, sein Werk, seine Wirkung. De Gruyter, Berlin, pp 89-103 
Ebbesen S (1986) A Chimera's Diary. In: Knuuttila S, Hintikka J (eds) The Logic of Being. Kluwer, Dordrecht, pp 115-143

Jacobs W (1979) Aristotle and Nonreferring Subjects. Phronesis 24:282-300

Kahn C (1966) The Greek Verb 'To Be' and the Concept of Being. Foundations of Language 2.3:24565

Kneale W, Kneale M (1963) The Development of Logic. Clarendon Press, Oxford

Knuuttila S (2015) Medieval Theories of Future Contingents. In: Zalta EN (ed) The Stanford Encyclopedia of Philosophy, URL = <https://plato.stanford.edu/archives/win2015/entries/medievalfutcont/>

Lewry P O (1978) Robert Kilwardby's writings on the Logica vetus studied with regard to their teaching and method. Unpublished PhD Dissertation, University of Oxford

Lewry P O (1981) The Oxford Condemnations of 1277 in grammar and logic. In: Braakhuis HAG, Kneepkens CH, de Rijk L M (eds) English Logic and Semantics from the end of the Twelfth Century to the Time of Ockam and Burleigh. Ingenium, Nijmegen, pp 235-78

Magee J (1989) Boethius on Signification and Mind. Brill, Leiden

McMahon W E (2003) Some Non-Standard Views of the Categories. In: Biard J, Rosier-Catach I (eds) La tradition médièvale des Categories XIIe-XVe siècles. Peeters, Louvain-Paris, pp 53-67

Mora-Márquez AM (2014) Martinus Dacus and Boethius Dacus on the Signification of Terms and the Truth-Value of Assertions. Vivarium 52:23-48

Mora-Márquez AM (2015) The Thirteenth-Century Notion of Signification. Brill, Leiden

Priscian, Institutiones grammaticae. Ed. Keil H. Olms, Hildesheim, 1961

Robert Kilwardby, Notule super librum Peryermenias. Ed. Conti A (forthcoming) (=DI)

Robert Kilwardby, De ortu scientiarum. Ed. Judy A. Oxford University Press for the British Academy, Oxford, 1976 (=DOS)

Robert Kilwardby, Notule Libri Posteriorum. In: Cannone D (ed) Le Notule Libri Posteriorum di Robert Kilwardby nella tradizione esegetica latina medievale del XIII secolo. Unpublished Dissertation, Rome University, 2003/2004 (=NLP)

Robert Kilwardby, Notule Libri Priorum. Ed. and trans. Thom P, Scott J. Published for The British Academy by Oxford University Press, Oxford, 2015 (=NLPri)

Roger Bacon, An Unedited Part of Roger Bacon's 'Opus maius': 'De signis. Ed. Fredborg KM, Nielsen L, Pinborg J, Traditio 34 (1978), 75-136

Silva JF (2012) Robert Kilwardby on the Human Soul. Plurality of Forms and Censorship in the Thirteenth Century. Brill, Leiden 
Silva JF (2016) Robert Kilwardby. In: Zalta EN (ed) The Stanford Encyclopedia of Philosophy, URL $=<$ https://plato.stanford.edu/archives/win2016/entries/robert-kilwardby/ $>$

Silva JF (2017) What Source: Textbook or Original Text? The Use of Florilegia by Robert Kilwardby.

In: Meirinhos J, Hamesse J (eds) Les Auctoritates Aristotelis, leur utilisation et leur influence chez les auteurs médiévaux. Brepols, Porto, pp 39-49

Steel C (2009) Albert's use of Kilwardby's Notulae in his Paraphrase of the Categories. In: Honnefelder L, Möhle H, del Barrio SB (eds) Via Alberti. Texte-Quellen-Interpretationen. Aschendorff, Münster, pp 481-507

Tabarroni A (2003) The 10th Thesis in Logic Condemned at Oxford in 1277. In: Braakhuis HAG, Kneepkens CH (eds) Aristotle's Peri Hermeneias in the Latin Middle Ages. Essays on the Commentary Tradition. Ingenium Publishers, Groningen-Haren, pp 339-61

Thom P (2007) Logic and Ontology in the Syllogistics of Robert Kilwardby. Brill, Leiden

Uckelman S, Lagerlund H (2016) Logic in the Latin Thirteenth Century. In: Duthil-Novaes C, Read S (eds) The Cambridge Companion to Medieval Logic. Cambridge University Press, Cambridge, pp $119-41$

Wedin MV (1990) Negation and Quantification in Aristotle. History and Philosophy of Logic $11: 131-50$

Whitaker CWA (2008) Aristotle's De Interpretatione. Contradiction and Dialectic. Oxford University Press, Oxford

William of Ockham, Summa Logicae. Ed. Boehner P, Gál G, Brown S. Opera Philosophica 1. Franciscan Institute Publications, St. Bonaventure, 1974 